\title{
THE RELATIONSHIPS OF THE TYPES OF ENTRY SELECTION OF STUDENTS WITH THEIR LEARNING MOTIVATION, LEARNING STRATEGIES, AND LEARNING ACHIEVEMENT.
}

\author{
Ashaeryanto*, Tri Nur Kristina**, Tridjoko Hadianto*** \\ * Faculty of Medicine, Universitas Halu Oleo - Indonesia \\ ** Department of Medical Education, Faculty of Medicine, Universitas Diponegoro - Indonesia \\ *** Department of Parasitology, Faculty of Medicine, Universitas Gadjah Mada - Indonesia
}

\begin{abstract}
Background: The learning achievement of students in higher education is reflected in their grade point average (GPA). Selection types in student admission, learning motivation, and learning strategies are believed to influence the effective and efficient learning achievement, thus facilitating achieving the desired learning objectives. Medical students should have good behavior and learning styles that eventually can help to make lifelong learning. Students that can organize themselves to learning tend to use a good strategy in running the study. Learning motivation and learning strategies used by the learner will affect student results. This study aimed to compare the 3 types of selection in student admission to learning motivation, learning strategies and achievement of students of the Faculty of Medicine.

Method: This was a quantitative study using a cross sectional design. The subjects were preclinical students at the Faculty of Medicine of Halu Oleo University, Kendari, consisting of 161 first-year students, 137 second year students, and 148 third year students. This study used a questionnaire 'Motivated Strategies for Learning Questionnaire (MSLQ)' to measure learning motivation and learning strategies. The results of MSLQ and GPA were compared based on the type of student selection.

Results: Within all categories of learning achievement, the highest scores were achieved by the students from selection of SBMPTN, followed by SNMPTN, then SLMPTN. Mean of extrinsic goal orientation of students with all types of student selection was high, whereas the lowest mean was learning self-confidence. Learning strategy with high score was repetition, and the lowest score was critical thinking in students with all types of student's selection. There was a positive relationship between admission style, learning motivation, learning strategies and achievement of students.

Conclusion: Students that were selected by SBMPTN have highest score of learning achievement, and the lowest score were students from SLMPTN. There was no significant different of motivation and learning strategy between all type of student selection.
\end{abstract}

Keywords: Student selection, learning achievement, learning motivation, learning strategies

\section{ABSTRAK}

Latar belakang: Prestasi belajar mahasiswa di perguruan tinggi dimunculkan dalam bentuk Indeks Prestasi Kumulatif (IPK). Seleksi mahasiswa, motivasi belajar dan strategi belajar memberikan pengaruh dalam tercapainya belajar yang efektif dan efisien sehingga akan memudahkan mencapai tujuan belajar yang diinginkan. Mahasiswa kedokteran sebaiknya memiliki perilaku dan gaya belajar yang dapat membantu untuk melakukan pembelajaran seumur hidup. Mahasiswa yang dapat mengatur dirinya sendiri dalam belajar cenderung menggunakan strategi yang baik dalam menjalankan pembelajaran. Motivasi dan strategi belajar yang digunakan oleh pembelajar akan mempengaruhi hasil

Contact: ashaeryanto@yahoo.com 
belajar. Penelitian ini bertujuan untuk membandingkan 3 jenis seleksi mahasiswa terhadap motivasi belajar, strategi belajar dan prestasi belajar mahasiswa Fakultas Kedokteran.

Metode: Penelitian kuantitatif dengan menggunakan rancangan potong lintang. Subjek penelitian adalah mahasiswa pre klinik di Fakultas Kedokteran Universitas Halu Oleo Kendari yang terdiri dari Mahasiswa tahun pertama berjumlah 161 orang, tahun ke dua berjumlah 137 orang dan tahun ke tiga berjumlah 148 orang. Penelitian ini menggunakan kuesioner Motivated Strategies for Learning Questionnaire (MSLQ) untuk mengukur motivasi belajar dan strategi belajar. Hasil MSLQ dan IPK dibandingkan berdasarkan jenis seleksi mahasiswa

Hasil: Pada semua kategori prestasi belajar, mahasiswa yang masuk melalui seleksi SBMPTN memiliki rerata tertinggi diikuti SNMPTN kemudian SLMPTN. Mahasiswa yang masuk melalui SBMPTN, SNMPTN dan SLMPTN memiliki rerata orientasi tujuan ekstrinsik yang tertinggi sedangkan yang terendah adalah kepercayaan diri belajar $\mathcal{G}$ prestasi. Nilai rerata tertinggi dari strategi belajar yang digunakan oleh mahasiswa dari 3 jalur seleksi tersebut adalah pengulangan sedangkan rerata terendah adalah berpikir kritis. Terdapat hubungan yang bermakna antara motivasi dengan prestasi belajar dan strategi dengan prestasi belajar.

Kesimpulan: Mahasiswa yang masuk melalui SBMPTN memiliki prestasi belajar yang lebih tinggi, kemudian SNMPTN dan yang terendah adalah SLMPTN. Tidak ada perbedaan yang signifikan antara mahasiswa yang masuk melalui ke 3 jalur tersebut terhadap motivasi dan strategi belajar.

Kata kunci: seleksi mahasiswa, prestasi belajar, motivasi belajar, strategi belajar

\section{INTRODUCTION}

Learning achievement is the maximum result achieved by someone who has made an effort to learn. In learning, one will always have a desire or a hope to accomplish optimal result in order to accomplish high learning achievement. The result of that learning process may also be an improvement and a development of a previously owned competence. ${ }^{1}$ Students' learning achievement in college is in the form of Grade Point Average (GPA). ${ }^{2}$

According to Biggs, learning is a system consisting of an input, a process, and an output. Learning achievement is the output of a learning process. Learning output is greatly influenced by input and process factors. Input factors in learning include students' prior knowledge, students' competence, intelligence quotient (IQ), students' personality, and students' family background. ${ }^{1}$ If the input and the process run well, quality learning outcome will be obtained in accordance with the standards to be achieved.

McManus from St. Mary's Hospital did a wide research on how medical students learn, believing that learning styles was a better predictor to determine students' next performance. ${ }^{3}$
Student entry selection performed by McMaster University, Hamilton, Ontario, Canada was done by observing students' early performance through a tutorial simulation design to know students' capability to solve problems in a small group. ${ }^{4}$ Lowry stated that the ideal way to select medical students was to select those who had the behavior and learning styles which might help them to do a lifelong learning. Furthermore, strong motivation is needed by medical students, either intrinsic or extrinsic motivation, to engage in the education process in medical education. ${ }^{4,5}$

The tightness of an entry selection is the early step to guarantee students' quality in accordance with the established standards. Referring to the principles of The Rules of the National Minister of Education in 2010 that are justice and non-discriminative i.e. do not discriminate ethnics, races, religions, social statuses, and the economic background of the prospective students, as well as still considering the potency of the prospective students and the specialty of the college and is done transparently and accountably where the registration, selection, and the announcement is done openly, as well as accepting new students according to the capacity of the study program. ${ }^{6}$ 
Vallie et al. did a research about self-regulation profile in learning and students' academic achievement in Public University in Northern Spain. This research by Vallie et al. used test grades as the academic achievement, so that they were not able to see learning achievement on the whole., ${ }^{4,5}$ A similar study was also performed by Van Den Hurk which correlated learning regulation to students' academic achievement in Faculty of Psychology, Maastricht University, Netherlands. However, in that study, Van Den Hurk only studied first-year students, so that he were only able to see first-year students' selfregulation. ${ }^{7}$ That research were not able to see higherlevel students' self-regulation which possibly had changed. In this study, the samples used first-, second-, and third-year students, so that we might analyze the picture of learning strategies and motivation in each level and its relationship with students' learning achievement. This study also compared the types of entry selection of the students.

\section{METHODS}

This was a quantitative research using analytic cross-sectional design to analyze the comparison of the types of entry selection of students to their learning motivation, learning strategies, and learning achievement in Faculty of Medicine, Universitas Halu Oleo (FM UHO), Kendari, Southeast Sulawesi Province in May and June 2016. The sampling in this research used total population, which was the whole preclinical medical students of FM UHO (161 first-year students, 137 second-year students, and 148 third-year students).

The dependent variables in this research were learning motivation, learning strategies, and learning achievement. Meanwhile, the independent variable was the types of entry selection of students. The instrument used to measure learning achievement was secondary data in the form of Grade Point Average (GPA). To obtain the picture of the types of selection of students, the types of selection were observed when they registered to college. This research also used a questionnaire to obtain quantitative data to measure students' learning motivation and learning strategies, namely the Motivated Strategies for Learning Questionnaire (MSLQ), developed by National Center for Research to Improve Postsecondary Teaching and Learning, University of Michigan. ${ }^{8}$

Data collection was done gradually. First, quantitative data in the form of secondary data of medical students' GPA in FM UHO were obtained, then second, the data about the types of selection of students when they registered to college. Afterwards, data collection using a questionnaire was done to each level of students in the morning before class. Researchers accompanied students during answering the questionnaire. Every questionnaire to be delivered to students had a consent paper attached to it. The consent paper included students' consent and demography data forms to fill. Researchers received an approval from the Medical Research Ethics Commission of Faculty of Medicine, Universitas Gadjah Mada.

Data obtained in this research was analyzed using SPSS ver 17.0. Descriptive data were used to see the mean, modus, median, and standard deviation of each students' sex, types of selection, MSLQ scores of learning motivation and strategies, and GPA of each student level. Bivariate analysis was used to analyze the relationships among MSLQ scores, types of selection of students, and learning achievement, using Pearson test.

\section{RESULTS AND DISCUSSION}

This research involved a total of 452 students (150 class of 2013 students, 141 class of 2014 students, and 161 class of 2015 students) with a response rate of $100 \%$. 
Table 1. The number of respondents (students)

in each level

\begin{tabular}{cccc} 
Year & $\begin{array}{c}\text { Number of Students } \\
\text { (person) }\end{array}$ & $\begin{array}{c}\text { Number of Respondents } \\
\text { (person) }\end{array}$ & $\begin{array}{c}\text { Response } \\
\text { Rate }\end{array}$ \\
\hline 2013 & 150 & 150 & $100 \%$ \\
2014 & 141 & 141 & $100 \%$ \\
2015 & 161 & 161 & $100 \%$ \\
\hline Total & 452 & 452 & $100 \%$ \\
\hline
\end{tabular}

There were differences of respondents' sex characteristics (Table 2), where in each level the number of female students were higher than male. The highest difference of respondents' sex was observed in class of 2013. Class of 2014 had the least number of students compared to the other levels, with 141 students $(31.19 \%)$ of all the total respondents.

Table 2. The number of respondents according to sex

\begin{tabular}{cccc}
\hline Year & Male & Female & Total \\
2013 & $34(7,52 \%)$ & $116(25,63 \%)$ & $150(33,19 \%)$ \\
2014 & $42(9,29 \%)$ & $99(21,90 \%)$ & $141(31,19 \%)$ \\
2015 & $46(10,18 \%)$ & $115(25,44 \%)$ & $161(35,62 \%)$ \\
\hline Total & $122(26,99 \%)$ & $330(73,01 \%)$ & $452(100,00 \%)$ \\
\hline
\end{tabular}

\section{Learning Motivation}

The parameter for learning motivation was presented in Table 3, where the highest mean of intrinsic goal orientation sub dimension was found in students who were selected through SBMPTN, while the lowest mean was in students who were selected through SNMPTN. The highest mean of extrinsic goal orientation sub dimension was in SBMPTN students, while the lowest was in SNMPTN students. The highest mean of the task value sub dimensions was in the SBMPTN students, while the lowest was in SNMPTN students. The highest mean of learning confidence control sub dimension was in SBMPTN students, while the lowest was in SNMPTN students. The highest mean of confidence to learn and to achieve sub dimension was in SLMPTN students, while the lowest was in SNMPTN students. The highest mean of confidence sub dimension was in SLMPTN students, while the highest was in SBMPTN. The highest mean of anxiety sub dimension was in SNMPTN students, while the lowest was in SLMPTN students. 
Table 3. Mean and standard deviation of each sub dimension according to types of entry selection

\begin{tabular}{lccccccc} 
& \multicolumn{2}{c}{$\begin{array}{c}\text { SBMPTN } \\
\text { Sub-dimensions }\end{array}$} & \multicolumn{2}{c}{$\begin{array}{c}\text { SLMPTN } \\
(\mathbf{n}=\mathbf{1 8 3})\end{array}$} & \multicolumn{2}{c}{$\begin{array}{c}\text { SNMPTN } \\
(\mathbf{n}=\mathbf{9 5})\end{array}$} & \multicolumn{2}{c}{\begin{tabular}{c} 
174) \\
\cline { 2 - 7 }
\end{tabular}} & Mean & SD & Mean & SD & Mean & SD \\
\hline Intrinsic goal orientation & 5,54 & 0,76 & 5,53 & 0,71 & 5,40 & 0,81 \\
Extrinsic goal orientation & 6,18 & 0,70 & 6,20 & 0,69 & 6,11 & 0,75 \\
Task value & 5,88 & 0,64 & 5,86 & 0,70 & 5,76 & 0,73 \\
Learning confidence control & 6,11 & 0,61 & 6,02 & 0,68 & 5,94 & 0,65 \\
Confidence to learn and achieve & 5,05 & 0,72 & 5,18 & 0,63 & 5,02 & 0,83 \\
Anxiety & 5,27 & 0,96 & 5,24 & 0,93 & 5,29 & 0,93 \\
\hline
\end{tabular}

The learning motivation dimension had 6 sub dimensions which can be measured using these research processes:

a. Intrinsic goal orientation - The mean scores of intrinsic goals orientation from the highest to the lowest were of SBMPTN, SLMPTN, and SNMPTN students, respectively. SBMPTN students had the highest mean compared to the others because SBMPTN is a written test selection whose participants were from all over Indonesia, so that the selectiveness is very tight. Prospective students' passion to be accepted was very high to compete for the limited seats. Those who had great desire would study as much as possible to be accepted through this type of selection. If compared to the other types of selection, such as SNMPTN or SLMPTN, where the types of selection were based on students' achievement in high school, students might have had achieved greatly in high school, but they might not have had strong motivation to learn medicine.

b. Extrinsic goal orientation - The mean scores of extrinsic goals orientation from the highest to the lowest were of SLMPTN, SBMPTN, and SNMPTN students, respectively. The selection through SLMPTN had the highest mean compared to the others. During the selection, this type of selection was held the latest after the other two selection had been held. Much possibly, outer motivation dominated the students who registered through this selection, such as from the environment or parents and family. It suits the definition of extrinsic motivation, i.e. encouragement from outside the students themselves. ${ }^{8,9}$ Extrinsic goal orientation or better known as extrinsic motivation is a stimulus encouragement from outside of an individual in learning. This motivation is still needed to boost students' passion. ${ }^{8}$

c. Task value - The mean scores of the task-value from the highest to the lowest were of SBMPTN, SLMPTN, and SNMPTN students, respectively. Students who registered through SBMPTN selection had the highest mean of task value to make it the motivation to learn. During the SBMPTN process, prospective students was tested with Academic Potential Test, Basic Subject Area Test, and Basic Competence Test so that they might pass and be accepted in their own choices. By intelligence, students in this type of selection had been proven to do learning tasks during the education process. ${ }^{9}$

d. Learning confidence control - The mean scores of learning confidence control from the highest to the lowest were of SBMPTN, SLMPTN, and SNMPTN students, respectively. Students who registered through SBMPTN had the highest mean of learning confidence control compared to the others. It is conventional for students of this type of selection to try really hard to pass. By studying as much as possible, self-confidence to learn will grow. If students believe that their effort will make a difference in learning, they 
will study more effectively. Learning confidence control is students' confidence in their effort to obtain positive results. ${ }^{9}$

e. Confidence to learn and to achieve - The mean scores of the confidence to learn and to achieve from the highest to the lowest were of SLMPTN, SBMPTN, and SNMPTN students, respectively. The sub dimension of confidence to learn and to achieve consist of two aspects, namely the expectation for success and self-confidence. Self-confidence in learning may affect the effort and the fortitude to face obstacles. The higher the self-confidence, the bigger the effort and fortitude. When a student faces a problem in achieving something, we expect him/her not to give up and attempt until the goal is achieved. Failure is considered as the lack of effort, not as an incapability. ${ }^{10,11}$

f. Anxiety - The mean scores of the anxiety from the highest to the lowest were of SNMPTN, SBMPTN, and SLMPTN students, respectively. Anxiety for examination consists of worries and emotion. A study by Darjono \& Amurwaningsih demonstrated that students with low anxiety had higher GPA. This conforms well to current study which shows that SBMPTN students with high academic achievement had lower anxiety. Students who worried about the consequences of failure when doing an exam showed a positive relationship with learning achievement. This may be because they did not want to fail the exam, so that they studied harder. ${ }^{11,12}$

\section{Learning Strategies}

The parameter for learning strategies is presented in Table 4, where the highest mean score of rehearsals sub dimension was in SLMPTN students, while the lowest was in SBMPTN students. The highest mean score of elaboration sub dimension was in SLMPTN students, while the lowest was in SBMPTN students. The highest mean score of organization sub dimension was in SLMPTN students, while the lowest was in SBMPTN students. The highest mean score of critical thinking sub dimension was in SLMPTN students, while the lowest mean was in SBMPTN students. The highest mean score of self-regulation metacognitive sub dimension was in SLMPTN students, while the lowest was in SBMPTN students. The highest mean score of time management and learning environment sub dimension was in SLMPTN student, while the lowest was in SNMPTN students. The highest mean score of effort management was in SLMPTN students, while the lowest was in SNMPTN students. The highest mean score of learning peers sub dimension was in SLMPTN students, while the lowest was in SBMPTN. The highest mean score of help seeking sub dimension was in SNMPTN students, while the lowest was in SBMPTN students.

Table 4. The mean and standard deviation in each sub dimension of learning strategies according to types of selection

\begin{tabular}{lcccccc}
\multirow{2}{*}{\multicolumn{1}{c}{ Sub-dimensions }} & \multicolumn{2}{c}{ SBMPTN } & \multicolumn{2}{c}{ SLMPTN } & \multicolumn{2}{c}{ SNMPTN } \\
\cline { 2 - 7 } & Mean & SD & Mean & SD & Mean & SD \\
\hline \multirow{2}{*}{ Rehearsals } & 5,31 & 0,90 & 5,51 & 0,86 & 5,35 & 0,90 \\
Elaboration & 4,96 & 0,86 & 5,08 & 0,76 & 5,02 & 0,86 \\
Organization & 5,06 & 1,09 & 5,28 & 1,19 & 5,10 & 1,05 \\
Critical thinking & 4,76 & 0,86 & 4,86 & 0,78 & 4,79 & 0,84 \\
Self-regulation metacognitive & 4,96 & 0,60 & 5,09 & 0,52 & 4,99 & 0,60 \\
Time management and learning environment & 5,27 & 0,58 & 5,37 & 0,51 & 5,22 & 0,59 \\
Effort management & 4,82 & 0,79 & 4,96 & 0,76 & 4,78 & 0,82 \\
Learning partners & 4,96 & 1,04 & 5,09 & 1,11 & 5,00 & 1,07 \\
Help-seeking & 4,88 & 0,75 & 4,93 & 0,76 & 4,95 & 0,75 \\
\hline
\end{tabular}


Learning strategies dimension had 9 sub dimensions which can be measured from these processes:

a. Rehearsals - The mean scores of rehearsals subdimension from the highest to the lowest were of SLMPTN, SNMPTN, and SBMPTN students, respectively. Rehearsals strategy is good for simple tasks and for saving new information into long term memories which will affect attention and coding process in students, but will not help students to link internal construction or to integrate information with previous knowledge. If this strategy is dominant and a student does not seek other strategies, then learning achievement will decrease in medical education. ${ }^{9}$

b. Elaboration - The mean scores of the elaboration sub-dimension from the highest to the lowest were of SLMPTN, SNMPTN, and SBMPTN students, respectively. Elaboration strategy will help students to save information into long term memories by linking learned studying materials. Elaboration includes paraphrase, conclusions, analogy making, and note writing. Elaboration also triggers knowledge reorganization, knowing differences, and keeping students thinking., ${ }^{9} 10$

c. Organization - The mean scores of the organization sub-dimension from the highest to the lowest were of SLMPTN, SNMPTN, and SBMPTN students, respectively. Organization strategy helps students to choose information and to link learned information. Organizing is an active activity, full of effort, and results in students to be involved in their tasks, which then will have an impact as good achievement. ${ }^{10}$

d. Critical thinking - The mean scores of critical thinking sub-dimension from the highest to the lowest were of SLMPTN, SNMPTN, and SBMPTN students, respectively. Critical thinking strategy is students' capability to use prior knowledge in current new situation in solving problems, making decisions, or critically evaluating. A study by Pratama showed that there was no correlation between GPA and critical thinking capability. It is in accordance with a study by Printrich et al. saying that critical thinking sub dimension had weak positive relationsip with academic achievement. This conforms well to this study where SLMPTN students has low academic achievement, although critical thinking strategy is dominant in learning. ${ }^{9-11}$

e. Self-regulation metacognitive - The mean scores of the self-regulation metacognitive sub-dimension from the highest to the lowest were of SLMPTN, SNMPTN, and SBMPTN students, respectively. Metacognition in self-regulation includes plans, observation, and regulation. A study by Hidayat showed significant, positive correlation between metacognition and learning achievement. However, a study by Pintrich et al. showed weak correlation between self-regulation metacognition and learning achievement. This conforms to current study where students who dominantly use this strategy in learning have lower academic achievement. ${ }^{11,12}$

f. Time management and learning environment - The mean scores of time management and learning environment sub-dimension from the highest to the lowest were of SLMPTN, SBMPTN, and SNMPTN students, respectively. Overall mean of all students is higher than 5, which means that this strategy is used by quite many students. Time management includes scheduling, planning, and managing learning times. Ideal learning environment is quiet environment with relatively low visual and auditory disturbance. ${ }^{12}$

g. Effort management, learning partners, help seeking - The mean scores of the effort management, learning partners, and help seeking sub dimension from the highest to the lowest were of SLMPTN, SBMPTN, and SNMPTN students, respectively. Effort management is a self-management and reflects a commitment to finish one's learning goals, even when there are difficulties. Effort is important for students' academic success because not only does it denote commitment to goals, but also manages the continuation of the use of learning strategies. Learning partners is a positive influence in reaching good academic achievement. Peer conversation may help students to clarify difficult learning materials. The other sub dimension is help seeking. Good students are the ones who 
know what they do not know and then try to seek help. Many studies indicated that help from peers or especially lecturers might facilitate students to reach learning achievement. ${ }^{12,13}$

\section{Learning Achievement}

The description for learning achievement in Faculty of Medicine, Universitas Halu Oleo according to SBMPTN, SLMPTN, and SNMPTN selections are as follows.

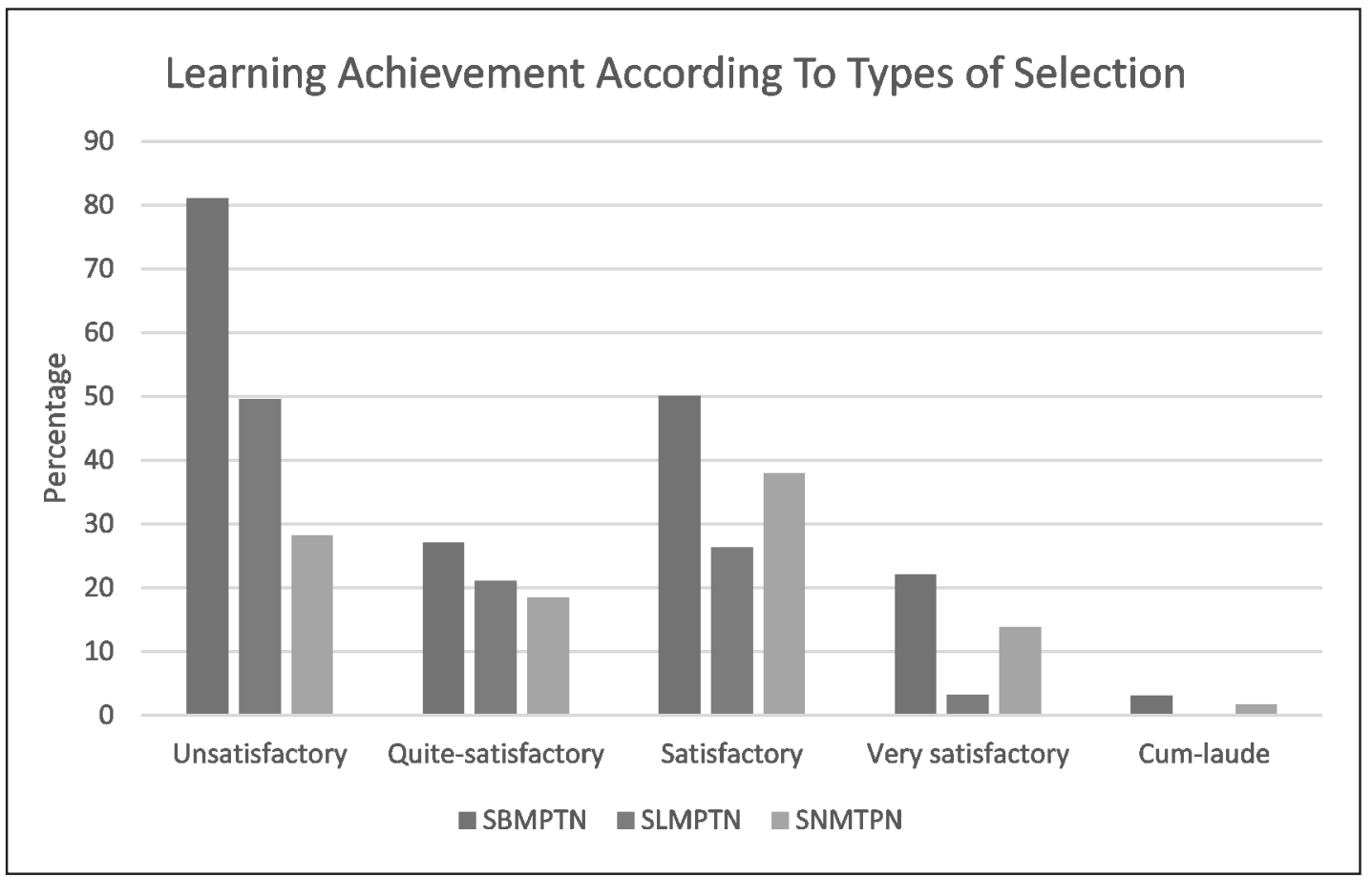

According to Figure 1, the majority of students in the unsatisfactory GPA category were from SBMPTN selection, and the least were from SNMPTN. The majority of students in the quite satisfactory GPA category were from SBMPTN selection, and least were from SNMPTN. In the satisfactory GPA category, the majority of students were from SBMPTN selection, and the least were from SLMPTN. In the very satisfactory GPA category, the majority of students were from SBMPTN selection, and the least were from SLMPTN. In cum laude category, the majority of students were from SBMPTN selection, while the least were from SNMPTN. There was not a student from SLMPTN selection who fell into cum laude category.

In cum laude, very satisfactory, and satisfactory categories, the order of the mean GPA from the highest to the lowest was SBMPTN, SNMPTN, and SLMPTN, respectively. There was not a student from SLMPTN selection in cum laude category. In the process of SBMPTN selection, prospective students were tested using Academic Potential Test (APT), Basic Competence Test, and Basic Subject Area Test. The registrants who took this selection were from all over Indonesia, so the selectiveness is very tight. Students who were accepted through this selection automatically had high APT scores and other competence scores. Therefore, this will correlate positively with learning achievement during education process. The low number of SLMPTN students in the satisfactory and very satisfactory categories, and even none in cum laude category, showed lower learning achievement. This is different from a study by Rahayu which stated that conceptually, in fact, student admission through report book selection was good which encompassed cognitive and non-cognitive aspects, which was based on an investigation of students' learning achievement history, complete with recommendations from teachers. ${ }^{9,10,12}$

In the unsatisfactory category, the order of the mean GPA from the highest to the lowest was SBMPTN, SLMPTN, and SNMPTN, respectively. Many of the students with unsatisfactory GPA were also found in SNMPTN students. The percentage of the number of accepted students through this selection was quite high. Even though, many previous studies stated that students with high APT scores would 
show high academic achievement. A study by Primartadi claimed that although using a different learning method, students with high academic potential competence tended to have better average grades compared to students with low academic potential competence. ${ }^{12,13}$

\section{Correlation between Learning Motivation and Learning Achievement}

The description for the correlation between learning motivation and learning achievement in Faculty of Medicine, Universitas Halu Oleo according to the entry selections using a test and using report books is as follows.

\section{a, Entry Selection through SBMPTN}

The analysis result using product moment showed significant correlation $(p=0.0)$ between learning motivation and learning achievement according to the entry selection using a test with a correlation value of $r=0.392$

\section{b. Entry Selection through SLMPTN}

The analysis result using product moment showed significant correlation $(p=0.01<0.05)$ between learning motivation and learning achievement according to the entry selection using a test with a correlation value of $r=0.483$.

c. Entry Selection through SNMPTN

The analysis result using product moment showed significant correlation $(p=0.01<0.05)$ between learning motivation and learning achievement according to the entry selection using a test with a correlation value of $r=0.347$.

The analysis results using product moment showed significant correlation between learning motivation and learning achievement, either in students accepted through SBMPTN, SNMPTN, or SLMPTN. Students with high learning motivation will have high learning achievement.

The results of this study conform well to a study by Lisiswanti which correlated motivation to students' multiple choice questions (MCQ) scores. Printich \& De Groot claimed that motivation itself was not enough for academic achievement success. Students need "desire" and "competence" to be successful in their education. ${ }^{13,14}$

\section{Correlation between Learning Strategies and Learning Achievement}

The description for the correlation between learning strategies and learning achievement in Faculty of Medicine,
Universitas Halu Oleo according to the entry selections using a test and report cards is as follows.

\section{a. Entry Selection through SBMPTN}

The analysis result using product moment showed significant correlation $(p=0.01<0.05)$ between learning strategies and learning achievement according to the entry selection using a test with a correlation value of $r=0.415$.

b. Entry Selection through SLMPTN

The analysis result using product moment showed significant correlation $(p=0.01<0.05)$ between learning strategies and learning achievement according to the entry selection using a test with a correlation value of $r=0.584$.

c. Entry Selection through SNMPTN

The analysis result using product moment showed significant correlation $(p=0.01<0.05)$ between learning strategies and learning achievement according to the entry selection using a test with a correlation value of $r=0.272$.

The analysis results using product moment showed significant correlation between learning strategies and learning achievement. Students with good learning strategies will have high learning achievement.

Vanzille-Tamsen demonstrated that self-regulation included motivation and strategies in learning was the basis of learning achievement. The process of selfregulation is related to the success of students' academic achievement. A study by Valle et al. showed statistically positive significant correlation between self-regulation in learning and students' academic achievement. This also means that students with higher self-regulation level in learning have higher academic achievement. Meanwhile, students with lower self-regulation in learning have lower academic achievement. ${ }^{14}$

\section{CONCLUSIONS}

According to the analyses and discussion above, it can be concluded that in all types of selection, extrinsic goal orientation had the highest mean, while self-confidence to learn and to achieve was the sub dimension with the lowest mean. From this study, it was also shown that students who were accepted through SBMPTN and SLMPTN had the highest mean to use rehearsals strategy and the lowest mean to use critical thinking in learning. Students who were accepted through SNMPTN had the highest mean to use rehearsals strategy and the lowest mean to use effort management strategy in learning. In cum laude, 
satisfactory, and very satisfactory categories, the highest mean to the lowest was students who were accepted through SBMPTN, SNMPTN, and SLMPTN, respectively. There was not an SLMPTN student who had a cum laude GPA. In the quite satisfactory category, the highest mean to the lowest was students who were accepted through SBMPTN, SLMPTN, and SNMPTN, respectively. In the unsatisfactory category, the highest mean to the lowest was students who were accepted through SBPMTN, SLMPTN, and SNMPTN, respectively. Lastly, there is a significant correlation between learning motivation and learning achievement as well as between learning strategies and learning achievement.

\section{RECOMMENDATIONS}

From this study, it is concluded that learning motivation should keep being improved by giving attention and motivation to all students, especially for students who need more attention in learning. Learning strategies management may be done by understanding concepts, theories, and practices coincidentally, so that students' mindset may be triggered to the higher level. SBMPTN students showed to have the highest achievement. On the other hand, however, students with this type of entry selection also fell in the unsatisfactory GPA category, so that the factors affecting it should be sought out. The weakness of this study was that this study only saw subjects in the preclinical stage of education, so that a continuation study needs to be done in the clinical stage.

\section{REFERENCES}

1. Anderson J, Hughes D, Wakeford R. Medical student selection: a tentative attempt to establish a code of practice. British Medical Journal. 1980: 1216-1980.

2. Biggs J, Kember D, Leung DYP. The revised twofactor study process questionnaire: R-SPQ-2F. British Journal of Educational Psychology, 2001;71:133-49.

3. Borg WR. Educational Research; An Introduction. Longman, London In: Cohen L, Manion L, Morrison K. Research Methods in Education. London: Routledge; 2011.
4. Chan KW, Wong AKY, Lo ESC. Relational analysis of intrinsic motivation, achievement goals, learning strategies and academic achievement for HongKong secondary students. The Asia-Pacific Education Researcher, 2012;21(2):230-43.

5. Curry L. Cognitive and Learning Styles in Medical Education. Academic Medicine, 1999;74(4):409-13.

6. Entwistle NJ. Approaches to learning and perceptions of the learning environment. Higher Education, 1991;22:201-4.

7. Entwistle NJ. Promoting deep learning through teaching and assessment: conceptual frameworks and educational context. 2000

8. Ginsberg BM. Cultural Diversity, Motivation, and Differentiation. Theory into practice, 2005;44(3):21825.

9. Lievens F, Coetsier P. Situational test in student selection : An Examination of Predictive Validity, Adverse Impact and Construct validity. International Journal of selection and assessment,2002;10(4):245-57.

10. Lowry S. Student Selection. British Medical Journal, 1992;305:1352-4.

11. Pola Penerimaan Mahasiswa baru Program Sarjana Pada Perguruan tinggi yang dilaksanakan oleh pemerintah 2010. Jakarta: Direktorat Jendral Pendidikan Tinggi Kementerian Pendidikan Nasional; 2010.

12. Powis DA, Neame RLB, Bristow T, Murphy LB. The Objective structured interview for medical student selection. British Medical Journal, 1988;296:765-8.

13. Proposal Pendirian Fakultas Kedokteran Universitas Haluoleo. 2011. Kendari : Fakultas Kedokteran Universitas Haluoleo; 2011.

14. Romanelly F, Bird E. Learning styles: A review of theory, application, and practices. American Jorunal of Pharmaceutical Education, 2009;73(1):1-9.

15. Ryan RM, Deci EL. Intrinsic and extrinsic motivation: Classic definitions and new directions. Educational Psychology, 2000;25:54-67. 